\title{
Practice of Fetish-Badri in Healing a Possessed Among the People of Kala-Balge Local Government Area, Borno State, Nigeria: An Islamic Perspective
}

\author{
Abubakar Shettima \\ Kashim Ibrahim College of Education, Maiduguri, Borno State. \\ bukshettima13@gmail.com \\ Kasim Alkali \\ Nigerian Arabic Language Village, Ngala Borno State \\ kasimalkali9@gmail.com \\ Mohammed Maga Sule \\ Department of Islamic Studies, Usmanu Danfodiyo University, Sokoto, Nigeria \\ mohammed.maga@yahoo.com
}

Naskah diterima:23-02-2018, direvisi: 25-05-2018, disetujui 30-07-2018

\begin{abstract}
Abstrak
Penelitian ini merupakan studi banding tentang 'Fetish-Badri' menurut pandangan Islam, dengan kasus pada masyarakat Kala Balge. Kajian ini meneliti peran yang dimainkan oleh penduduk dalam interaksi dengan 'Fetish-Badri'. Adapun instrumen pengumpulan data berupa wawancara, buku pelajaran, jurnal, disertasi, dan makalah seminar. Penelitian menemukan bahwa terdapat banyak pemilikan jenis obat tradisional di Borno yang berbeda menurut zona geo-politik. Sangat menarik untuk dicatat bahwa 'Fetish-Badri' sebagai obat memiliki hubungan dengan kekuatan supranatural. 'Fetish-Badri' adalah proses penyembuhan atau ritual yang berpusat pada keyakinan akan keberadaan kekuatan Jin yang memiliki korban dalam berbagai cara dan bentuk. Oleh karena itu, penelitian menemukan bahwa penduduk pedesaan menyukai pengobatan tradisional tersebut karena keyakinan bahwa semua praktik yang terlibat ditujukan untuk pengobatan dan penyembuhan. Dengan demikian beberapa praktisi fetisisme juga menganggapnya sebagai sarana hiburan dan memperoleh manfaat duniawi. Disarankan bahwa segala macam metode penyembuhan harus dipertimbangkan asalkan tidak bertentangan dengan ajaran Islam dan tidak membahayakan kehidupan masyarakat. Untuk mencapai hal ini, dianjurkan bahwa siapa pun yang ingin terlibat dalam teknik penyembuhan yang diperbolehkan seseorang harus mencari pengetahuan yang mendalam di lapangan dan untuk mengetahui aturan-aturan Islam dasar dalam hal metode, agar tidak membahayakan kehidupan kliennya.
\end{abstract}

\begin{abstract}
This research work is centered on a Comparative Study of Badri-fetish in the light of Islam, with particular reference to Kala Balge. In this regard the role played by the populace in interaction with Badri fetish was examined. To this matter, the researchers used interview as instrument for data collection. So also Textbooks, Journals, Dissertations, Seminar papers were also included. The research found out that there are many kinds of traditional possession remedies in Borno according to different geo-political zones. It is interesting to note that Badri-fetish as a remedy has a link with supernatural forces. Badri-fetish is a healing process or ritual centered on the belief in the existence of the power of Jinn which possess their victims in various
\end{abstract}


ways and forms. Therefore, the research found out that the rural dwellers are patronizing the aforementioned traditional remedy for the belief that all the practices involved are aimed at cure and healing. As such some of the fetishism practitioners have also regarded it as a means of entertainment and gain of worldly benefits. It is recommended that all sorts of healing methods should be considered provided they do not contravene to the teachings of Islam and if it may not harm or endanger the life of the people. To attain this it is recommended that whoever wants to engage in any permissible healing technique one must seek a deep knowledge in the field and to know the basic Islamic rulings in regards to his method, so as not to endanger the life of his clients.

Key words: Badri, fetish, Jinn, Possession, Healing

\section{Introduction}

Borno state was part and parcel of ancient Kanem-Borno Empire. Kanem-Borno was a centre of political, educational and economic activities. A.M Sifawa observed that Kanem Borno was one of the earliest states in Bilad Al-Sudan that have early contact with Islam. The kingdom therefore played a tremendous role in the social, religious, political and intellectual development of the area most especially in the area of dissemination of knowledge through production of literary works. These historical events were recorded through granting Mahrams to scholars and establishing centres of learning. As a result a very serious impact on the socio-economic well-being of the people in the area was recorded. After the collapse of the sayfawa dynasty, El-kanemi continued to exert the same impact (Sifawa, 1991, p. 133). Therefore, Borno is one of the two recognised and prominent seats of learning in Northern region of Nigeria; the other pair is Sokoto caliphate that was established by Shaikh Uthman Ibn Foduye in the nineteenth century (Sifawa, 1991, p. 135). So also the state capital Maiduguri was founded and adopted in 1907 by the British colonialists. It came into being as one of the Mega cities of Northern Nigeria (Tijjani, 2008, p. 50). Historically, the state is said to have been economically good because the early settlers engaged in different types of economic activities. These include farming of millet, corn, sorghum, groundnuts and other crops due to its huge fertile land for the production of farm produce. They also engaged in cattle rearing and hunting but hunting is of minor significance but more importantly fishing is an important resource to villages along the Lake Chad shores (Usman H.M, John , \& Usman H, 2011, p. 103). Kanuri is the dominant ethnic group occupying many of the respective twenty seven local Government Areas of the state.

Therefore, the people of Borno cannot be separated from Islam. However, the state had witnessed numerous changes in its cultural and other aspects in the post-colonial 
period. This was due to interactions with other people's cultures such as Hausa, Fulani, Gamargu Marghi, Papir, and others. These interactions led to the emergence of cult practice in healing of the sick. To the best of the researcher's knowledge there is no any cult or idol worshiping traced in the history of Borno after the advent of Islam. This was because Borno had a long history of contact with Islam and Sharia had been the guiding law of the land. The only semblance of cult in the history of Bornu was mune, which other scholars and historians referred to as an object considered sacred by the people even though they did not know it (Dierk, 1990, p. 266). It was something wrapped-up and concealed. None of the king's descendants from Sayf b. Ziyazan would open it due to its ambiguity. While other historians and scholars like Imam Ibn Furtua considered it as Qur'anic Constitution, however, due to this ambiguity Mai Dunoma Dibalemi disregarded the commandments concealed in the Mune as nothing rather than an extraction from the prophetic commandments.

However, not all aspects of Borno culture have been transformed by social changes and global urbanization due to occupation of Northern Nigeria by the British. Therefore, it remains strongly a traditional settlement with traditional culture of cure and healing as the practice of (Qur'ánic healing, Darni, Gau, (Herbalist), Safima (Magician), Kaskima (Soothsayer), Ngozoma (Traditional birth attendant). (Kaka, 2009, p. 100). Therefore, this research tends to examine the healing process of fetish-Badri among the people of KalaBalge.

\section{Scope and Limitation}

This research is on Badri-Fetish from theological perspective with particular reference to Kala-Balge of Borno State. Therefore, the scope of the study is limited to the Muslims residing within the aforementioned Local Government Area of Borno state.

\section{Significance of the Study}

Many researches have been conducted by different researchers on culture, Fetishism, traditional medicine and others, but little attention was given to the Islamic theological aspects in terms of Shirk and innovations involved in some of these practices.

1. The study is of value to those who indulge in practicing Badri and those who patronize them. 
2. The study will show that Islam and Tauhid are intertwined because there is no Islam without Tauhid. So committing shirk and innovations are not allowed, be it minor or major shirk.

3. The study will serve as a source of reference for interested researchers as it contributes to the existing body of literature.

These means are adopted by the priest to come closer to the Jinn. Thus, some people forget the assurance of the creator who says:

"And when I am ill, it is He who cures me" (Surat Ash-Shu'araa: 80).

According to Prophetic Traditions, the companions of the Prophet and saints offered prayers for the ill, and witnessed the recovery of those they prayed for. The Prophet was reported to have permitted the members of a certain family of the Ansar to recite incantation in (asking for) cure from (the effect of) poison (Sahih Ibn Khuzaimah, H, 2193). Healing practices involved prayer to Almighty Allah, use of Zamzam (holy water), honey etc. Some healers use other methods such as herbs and visiting a doctor. Therefore, Islam encourages a sick to seek for a treatment, but he should be guided by the teachings of Islam throughout the process.

\section{Statement of the Research Problem}

The concepts of Badri-fetish practices are aimed at cure and healing. In order to clear the doubt towards the various syncretic beliefs and practices those have hitherto clung onto by some of the members of the society on both the side of the healers and their clients. Some might not know the implication involved in their method of medication. The kind of shirk involved, include seeking cure and healing from magicians and soothsayers, using unintelligible words or phrases as supplication and relying on the power of someone other than Allah are also going to be assessed. Allah says:

And they learn that which harms them and profits them not. And indeed they knew that the buyers of it (magic) would have no share in the hereafter (Surah Al-Baqara: 102).

In addition to this, many people are mistakenly relating some ailments that have to do with feverish condition, to spirit possession and witchcraft. It is well known that some ailments require a long duration under treatment and some patients are impatiently looking for fast recovery, as a result of which people might resort to shirk and innovations. Eventually this attitude sometimes leads to death or unnecessary spending. Therefore, there 
is the need to investigate the theological aspects on healing of a possessed. Similarly the research provides the missing link of the Islamic theological aspects through answering the following questions.

1- In what situation does a possessed and a healer commit shirk and innovation in medication?

2- Why is it that the priests (badri) continue to operate despite the availability of Islamic way of treatment?

3- What are the ways and manners of conducting fetish-badri in the study area?

\section{Objectives of the Study}

1- Identify the practices of Fetish Badri among the people of Kala-Balge

2- Assess the kinds of Shirk (polytheism) involved in Fetish-Badri in the light of Islam.

\section{Methodology}

As the name implies, this section connotes the description of the procedure by which the researcher gathered the information and utilized it. For the purpose of achieving the objectives of this research work, interview method was adopted through interviewing the practitioners and their clients under the internally displaced person's camps which are clustered in Maiduguri metropolis. In this regard a chain referral sampling is applied. This method of sampling enables the researcher to select the required unit by contacting the first unit to be considered as part of the sample. Thereafter, the first unit met will be used as informant to get the subsequent units from the population of interest.

\section{Background of the Area of Study: Borno State}

Borno state is one of the thirty six states in Nigeria. It is located in North Eastern part of the country. It has almost the longest recorded history in the Nigerian historiography. It is against this background that different cultures of the world represented by the Chadic language speakers, which comprises Shuwa and Kanembu-Kanuri which brought about the predominant religion of Islam since the seventh century AD. Indeed, the significant development was the advent of Islam through Kawar Oases in C.667 AD when Uqbah bn Nafi led a military expansion to the area. Later on Kanem-Borno became a centre of political, educational and economic growth. The kingdom was named after a hero and a founder of the Sayfawa ruler known as Sayf bin Dhi Yazan around $9^{\text {th }}$ century C.E (Alkali, 
2012, p. 4). The historical events that followed the arrival of Sayfawa dynasty were the massive conquests and spread of Islam. As a result of the rising, falling, expanding and shrinking of some empires in Africa these impacted on the socio-economic well-being of the people. After the collapse of the Sayfawa dynasty, El-kanemi continued to exert the same impact (Tijjani, 2005, p. 17). Borno is one of the two recognised and prominent kingdoms that existed in Northern Nigeria; the other is Sokoto Caliphate that was established by Shaikh Uthman Ibn Foduye in the nineteenth century (Tijjani, 2005, p. 19).

The policy of state creation in the country started in 1963 when the mid-western region came into being. The period was characterized with pressing demands of creating more states. Four years later, twelve states were created out of the former regions. The Northern region was split into six states among which were the defunct North Eastern state. Later on, on $3^{\text {rd }}$ Feb 1976, the then Head of State, General Murtala Ramat Mohammed created additional seven states in the country making the total number nineteen. In this division, the North eastern part was divided into Borno, Bauchi and Gongola states now Adamawa state. Furthermore, more states were created on $27^{\text {th }}$ August 1991. A considerable portion of old Borno state was carved out to create Yobe state by the then military Head of State Ibrahim Badamasi Babangida (Borno state Government, 1993, p. 24). However, Borno state referred to as "Home of peace" as its slogan and later become volatile state due to aggression of the insurgents who repeatedly engaged in kidnapping, looting, burning and destruction of lives and properties (www.cometonigeria.com). Maiduguri is the state capital and popularly known as Yerwa for its well-being and goodness. Maiduguri (Yerwa) was founded and adopted in 1907 by the British colonialists. It came into being as one of the Mega cities of Northern Nigeria (Tijjani, 2008, p. 51). The city is well protected from rays and beams of the sunlight by Neem trees planted on the main roads and the various streets in order to protect the environment from drought and desertification (Mayomi. \& Mohammed, 2014, p. 2).

\section{Geographical Location of Borno State}

Due to the geographical location and ecological features of the state, the area has a short rainy season. The peasant farmers plant and harvest their crops from June to September (Cohen, 1967, p. 77). Consequently, the state has a hot and dry weather for a greater portion of the year, but the southern part of the state is partially mild. Excess heat of about 40 to $42^{0} \mathrm{C}$, is recorded, often the rising of temperature causes discomfort to the 
people. Borno is located within the latitude $10 \mathrm{~N}$ and $14 \mathrm{~N}$ and longitude $1130 \mathrm{E}$ and 14 $45 \mathrm{E}$, with the area of $61,435 \mathrm{sq}$ (www.cometonigeria.com, ). Presently, the state is bordered by three Countries. It is bordered to the north by Niger Republic; to the east by Chad Republic and Cameroon Republic to the South East (Tijjani, 2005, p. 19).

\section{People and their Occupation}

Borno state is quite heterogeneous with different kinds of people living in rural and urban areas of the state. It has an estimated population of about 4,151,193 as indicated in the 2006 census (Usman H.M, John , \& Usman H, 2011, p. 24). Borno is known to be a multi lingual town. There are many ethnic groups and immigrants who came to settle in the state. The dominant ethnic group occupying three quarters of the population of the state are Kanuri who have a long and rich history.

Historically, the state is said to have been economically good because the early settlers engaged in different types of economic activities. Majority of the people in the state are farmers and herdsmen. They believe that farming is one of the most important aspects of human development. It is the means of providing livelihood to the people in any society. They engage in farming of millet, corn, sorghum, cotton, fruits, guinea-corn, gum Arabic, beans, groundnuts and other crops due to the large fertile land conducive for the production of varieties of crops in the state.

The majority of the inhabitants of Kala-Balge are Mori, Kanuri and Shuwa. The vicinity of Kala which include Ndufu, Sigal and Rann the Headquarters; Ngala and Dikwa were referred to as the first sites of $S a$ ' $u$ kings (The Kanuri People referred Sa'u to Chadic speaking People who are today identified as Kotoko),

Ngizim, Bade and Mandara. It is worth recalling at this point that, the area was Islamized since arrival of Islam in Kanem Borno. In Islamic faith, every Muslim is mandated to believe in the unseen, which will directly or indirectly lead to the belief in 'Jinn' and other unseen creatures. The belief is that Jinn have the power to take different forms and shapes. There seems to be the influence of Islam on the inhabitants of the area. Notwithstanding, the people there stick to Badri healing as an effective remedy for Jinn's possession and other bodily diseases. Badri performance was not only tolerated as a form of possession remedy, but the organizers were respected and patronized (Lawan Mai Sigalma, 2016). This might be as a result of geographical location of the area. The area is dominated by huge trees of baobab, tamarind, eucalyptus which are believed to contain spirits (Rann, 2016). Others are of the view that such superstitious beliefs were due to the 
fact that there were no conventional hospitals or psychiatric hospitals in the area (Abiso, 2016).

\section{Socio-Cultural Background}

Socio-Cultural setting of people is a way of life with regards to their behaviour, belief system, attitudes, knowledge, life style and others. The aforementioned values distinguished the members of one social group from another. It is interesting to note that the Jinn are creatures of Allah like any other creatures. This is frequently mentioned in the Glorious Qur'an and the Prophetic Traditions of the Prophet (pbuh). Traditionally, Borno people believe in the existence of a number of spirits like Goigoi spirit. It is short in its physical structure and usually lives in forest, but comes to a nearby town or village to take away children. They also believe in Kolidam spirit which is very tall and not often seen, lives in a bush to call people's names in order to cause possessions. So also, the belief in Mairam kuruwu (tall) spirit is widely circulated within the people. This spirit is very tall in structure, mostly lives in caves, hallows and deserted buildings. It walks during the midnight to harm its victims. They also believe in Ngauram spirit which looks like an animal most especially ram or at times fish with human head. This kind of spirit usually lives in wells and rivers sometimes it harms people. There exists also the belief in witchcraft, those who have power and ability to afflict their victims by striking them (Ministry of Education, Borno State, 1995: 59). This brings about what is called Duwoduwo (Magic) in Borno and the practitioner is Duwo-duwoma (Magician). It is believed to be in form of imaginary mysterious powers that make people see actually something that is not real to be like real. For example, you can see somebody cutting some part of his body with a sharp blade with no effect.

It is believed in some instances that the power of charms, talisman, and amulets can give maximum protection from being harmed (Kaka, 2009, p. 116). Though, their magic formulation depends on the nature of protection required. For example amulet is worn around the body or neck for protection against a host of afflictions. Charm is used to seek protection against health related issues and talisman is believed to have magical powers for bringing good (Khalid, 2010, p. 290). This belief in magical power prevailed to the extent that some people cannot do without putting on some superstitious objects for the fear of calamities and to feel protected (Dahiru, 1986, p. 209). 


\section{Symptoms of Spirit Possession in Borno Central with Particular Reference to Kala Balge Local Government Area}

The symptoms of Spirit possession in Kala-Balge area are similar when compared to many places. The Jinn are classified into two; the Muslim Jinn and the Káfir Jinn who used to possess their victims at any time. A number of patients are troubled by either of the two. This might be identified through observing certain behaviours (Abiso, 2016). Thus, if the victim is engaged in doing good deeds, the interpretation is given that he is possessed by Muslim Jinn. However, if the patient engages in worldly affairs such as abusing or ceased to act piously the interpretation then is given as he is possessed by Káfir Jinn. Other symptoms of possession include paralyses, protracted illness, weight loss; over stayed wound (Lawan Mai Sigalma, 2016).

\section{The Physical Practices of Badri-Fetish}

Despite the fact that the people of Kala-Balge are predominantly Muslims, the method adopted by some of the people in healing a possessed seem to have been established on fetishism. When someone is afflicted with an ailment the only remedy is to invite the performers of Badri 'a healing fetish similar to Bori-Fetish' to undergo the first stage medication. The performance will start by the arrival of Badri leaders and their assistants together with musicians of shila. Shila is a kanuri word meaning flute. It is believed that Jinns used to gather at the scene of this kind of procession to listen and enjoy the Shila music. The musical performance has different tracks that represent names of Jinn. These names are Jindi Musa, Jindi Maimuna, Jindi Isa, Nana Mairam while the gamargu of Dikwa named the spirits as Sarkin Samari i.e. Hausa spirits, Aisami, Wainare, Jagargara who lives in river, Kashantamaka who lives in tamarind tree (Rann, 2016).The leader of the performance could be a male or female titled badrima. The role of these specialists is twofold: preparation of herbs and enchanting spirits. The chief priest will order the members of the family to prepare Bollo 'a mixture of masticated millet with water and sugar made into a small ball shape' then he starts rubbing it over the body of the patient for three to four days. If progress is recorded then the patient is healed, but if the rubbing remains in vain, Badri must be beaten.

Badri refers to the kind of treatment that is being practiced in Kala-Balge and Ngala axis as well as Gamargu tribe who are scattered in Dikwa, Konduga and Bama Local Government Areas. Likewise, Badri means 'drum' in Mori language. Therefore, the 
technical meaning is a treatment of a possessed through the use of songs and drum beating in order to calm the inflicted and to gain recovery. It is believed that spirits love music and entertainment that is why the drum is beaten so that the spirit will reveal itself while listening to its favourite rhythm. Some believe it as a treatment of sickness that fails to respond to medical treatment or any sickness associated with Spirits. The participants are males and females though the females outnumber the males. Thus, the performance of Badri ceremony could last for two to three consecutive days. The third day is called Kurugma 'i.e. beating the drums with hands but the first and second day beating of drums is with sticks. The occasion attracts almost all the community from far and near to attend the ceremony. It is interesting to note that the great gathering is not done by invitation rather the people will gather the moment they hear the sound of the drum and the blowing of the flute. Almost all the people gathered had either the experience of being possessed or have witnessed another being possessed by Jinn (Lawan Mai Sigalma, 2016). Each and every one of the audience contribute according to his wherewithal. When donating, the cash should be seen by everybody in the 'Dandal' where the ceremony is taking place. Then the patients will be attended to being accompanied by their relatives or family members. In a situation whereby the patient is severely ill he would be brought to the place to undergo the opening day ritual. There is a special cloth to be worn on the day, a white hat would be put on the patient's head then he is decorated in white gown handling a sword in his hand. Then, the drum is beaten continuously and the Shila flute is blown near the patient mentioning the names of the Jinn. The spirit will reveal itself the moment it hears its name in the favourite rhythm. Thus, it was believed that the Shila musical instrument itself is used to cure a possessed by drinking the water that passed through the instrument. Those that drank the water can stay safe during any performance (Kala, 2016).

The patient starts to dance to the drumming and possibly sing unknown songs, laughing aloud or crying. At the end the patient will show strange behaviour like speaking unintelligently in different languages. In some circumstances, they might assert interpretations that are queried. This shows that the patient is in a trance. Lastly, the patient falls down flat in the centre of the Dandal. Then, the slaughtered animal is revolved over the patient. When the Jinn tend to be stubborn the practitioners start to flog the patient (Kala, 2016). The secret behind the flogging is a threat to the Jinn in order to leave the victim. Interestingly, the flogging is applied under specific guide i.e. with a limited number of lashes and the condition of the possessed must be considered before the application of 
the lashes. Witnessing the utterances by the victim in an unknown language made them to believe in the power of the supernatural (Makinta, 2016).

Sacrifice of animals such as chicken, cocks, goat or cow is encouraged, because the blood of the sacrificed animal would be used in the session for sprinkling on the ground. In the process of slaughtering the animal they tilt the animal to face the direction of Ka'abah. Lastly, the healers ask the patient to stay in doors for at least three days to relax after the events. Thereby, the physical and psychological problems will disappear. Nowadays, the idea of practising Badri has considerably reduced because it is not holding in unison as it was practiced before. The assembly for Badri is done somehow in a hidden location without being noticed by a larger population (Kala, 2016).

\section{Islamic Ruling on Fetishism}

Many Islamic scholars are of the view that Jinn can possess his victim and afflict him. However, some scholars disagree and assert that Jinn can only influence mankind but it cannot take any part or physical space within a human body. To them, what has been said about it was only imaginary and illusions (Dein \& Illaiee, 2013, p. 291).

Wide spread superstitious beliefs developed for long in human societies. This had found its roots in animal totems (emblem made by a living creature to represent an object) which evolved over years to more complex beliefs. For example, charm, amulet, and magic were practiced among the Arabs during the Prophet's era. It could also be found in different parts of the world in different kinds and forms. In fact if they are not clearly addressed Muslims could easily commit shirk, for example if someone is afflicted by a sickness he might resort to magic and other unlawful remedies. By implication magical power relies on the power of Jinn. The contrived method for averting misfortune mostly used magic. Consequently, there are a number of Prophetic Traditions which strictly forbade such practices. The Prophet (pbuh) was reported to have said;

'Whoever goes to a soothsayer or fortune teller and believes in what he says has indeed rejected that which has been revealed to Muhammad' (Ash'ath)

In other Hadith the Prophet (pbuh) was reported to have said,

'The prayer of whoever approaches a fortune- teller and asks him about anything his prayer will not be accepted for forty days and nights' (Isma'il, 1987). 
However, there is no distinction between Magic and its branches like sorcery, witchcraft, divination and necromancy (Philip A. B., 1989, p. 44). As far as this is known, Sihr is defined in Arabic as magic, charm witchcraft, wizardry (Ba'alabaki, 1995, p. 626). The technical meaning of sihr is an art which stipulates that the magician commits impossible tricks or polytheistic acts with the help of Jinn (Ahmad, 2009, p. 10). Consequently, Islam rejects the impact of charm and amulet in regard to cure from possession, evil and attraction of good fortune. But it recognizes that some aspects of magic are true. This is evident in the Tradition of Prophet Muhammad where he himself suffered from the effect of magic.

Zaid bin Arqam reported that a Jew by the name of Labeeb Ibn A'sam casted a magical spell on the Prophet and when he began to suffer from it Angel Jibreel came to him and revealed the Mu'awwadhatani and said to him 'Surely, it was a Jew who cast this spell on you and the magical charm is in a certain well' the Prophet sent Ali bin Abi Talib to go and fetch the charm. When he returned with it, the Prophet told him to untie the knots in it, one by one, and recite a verse from the surah with it. When he did so the prophet got up as if he had been released from being tied up' (Ma'rouf, 2003, p. 251).

The aforementioned Hadith proves that some magic are real since the existence of Jinn is real. But most of the magic being practiced nowadays is clearly full of illusions designed to deceive audiences. Thus, there exist around the world some magicians that practice real magic resulting from their contacts with the Jinn. Allah (SWT) says;

'They followed what the Shayatin (devils) gave out (falsely of the magic) in the lifetime of Sulaiman. Sulaiman did not disbelieve, but the Shayatin (devils) disbelieved, teaching men magic' (Surah Al-Baqarah: 102).

Therefore, any form of magic done for a good or bad purpose is considered unlawful in Islam since it is repugnant to Tauhid. Islam provides solution to all problems of life, more particularly the treatment and cure of diseases. Allah (SWT) says;

And We send down of the Qur'an that which is a healing and a Mercy to those who believe (in monotheism and act on it), and it increases the polytheists and wrongdoers nothing but loss (Surah Al-Israa: 82).

This verse clearly indicates the existence of healing as a mercy and bounty from Allah, the Exalted. Therefore, if anybody gets sick he must resort to a lawful treatment. No any medical treatment against any disease is discouraged but also curative measure is encouraged (Sediq, 2010, p. 395). The Glorious Qur'an emphasizes on taking precaution in 
life; as to take a preventive measure against hellfire by following the stipulated commandments. In this regard disease could be prevented by lawful means.

It is unanimously agreed that Badri-fetish is connected with Jinn as it is a folk healing method. The main concept as well as the main cause of Badri performance is healing a sick person who is afflicted by Jinn. Thus, the victims of possession are afflicted without their will rather it is predestined by Allah. Spirits are kinds of creatures not visible to humans. Allah (SWT) says;

O children of Adam! Let not Shaitan deceive you, as he got your parents (Adam and Hauwa) out of paradise, stripping them of their raiments, to show them their private parts. Verily, he and his soldiers from the Jinns or his tribes see you from where you cannot see them. Verily, We made the Shayatin protectors and helpers for those who believe not (Surah Al-A'raaf: 27).

Consequently, Jinn are capable of appearing in different shapes such as human or animal. Besides that Jinn are capable of harming mankind, if not for the Angels that Allah ordered to protect humans from the aggression of Jinn. Nobody can defend himself from being afflicted. This is because Jinn's body is soft in such a way that it is beyond human vision (Muhammad, 2004, p. 29). Allah (SWT) says;

'No calamity befalls, but by the leave of Allah, and whoever believes in Allah, He guides his heart to the true faith with certainty and Allah is the All-knower of everything' (Surah At-Taghaabun: 11).

Therefore, Islamic religion has categorically calls for total submission to Allah's will, regardless of ones race, culture and any other affiliations. Muslims should shun the footsteps of the devil (Balogun, 2011, p. 256). The Muslim scholars unanimously agreed that any sacrifice meant to be delivered to Jinn is prohibited and it is shirk (Polytheism). Indeed the sacrificed meat should not be consumed by a Muslim (Muhammad, 2004, p. 21). Mostly, such practitioners claimed to have powers of healing. So also they prescribe certain animals to be sacrificed, as well as, smear the blood on the body of the possessed. Categorically, this act is considered to be shirk even if the name of Jinn is not mentioned in the process (Muhammad, 2004, p. 23). Therefore, prayers as Ruqyah are very significant in the Islamic tradition. Almost all Muslims are engaged in some form of prayers. There are supplications that are recommended to be offered during the times of affliction and calamity. This is evident in the supplications made by the Prophets in distress and illness. Prophet Ibrahim (A.S) invoked Allah to cure his affliction. The answering and acceptance of these prayers is Allah's will, not within human or Jinn power. It is the responsibility of 
the humans to say their supplications during, after and even before the needs. Supplications serve as weapon to a believer. They are admonished to invoke Allah's name in both times of adversity, distress and ease. This should be done with utmost sincerity and confidence in Allah (SWT)

\section{Findings and Conclusion}

The findings revealed that the treatment method employed by Badri-fetish involve different kinds of technicalities. Thus, it is ascribed to health and healing within an encompassing socio-cultural context.

It was noted that the Musical instruments used in Badri method of healing are Shila flute for blowing, Horn and Drum referred to as Badri. Thus, the name Badri is derived from the name given to the drum. It was also revealed that this method is used to heal possession, paralysis, barren condition, high fever and others. The method used in healing is to praise and compliment the spirit involved by calling names of the Jinn as Jindi Maimuna, Jindi Isa and other Jinns. This will lead the Jinn to appear when it hears its favourite name. The victim in trance is agitating and shivering until when they are made down by the members of the gathering present. Sometimes some of the attendants are implicated to become victims of possession. To this end Bollo (a mixture of grinded millet with sugar) is used to rub over the body of the victim as concoction of medicinal herbs are very important in the healing process. Sacrifice of animals like chicken or goat is encouraged in the process of healing as the healed members used to contribute money to the priests.

The results indicate that there are many remedies for evil possession in Borno according to the culture and geographical location of the inhabitants. There are priests (Bokaye) who are being patronized. Certainly, a long standing tradition of healing of the possessed among the people of Kala-Balge was unveiled. Notwithstanding, it was also revealed that there are those healers who used to promote 'Shirk' for worldly gains. As stated in the Glorious Qur'án in " $O$ you who believe! Verily, there are many of the Jewish and the Christian monks who devour the wealth of mankind in falsehood, and hinder (them) from the way of Allah (i.e. Allah's religion of Islamic Monotheism). And those who 
hoard up gold and silver and spend them not in the way of Allah, announce to them a painful torment (Surah At-Tawba: 34).

\section{Bibliography}

Abiso, U. (2016, July 28). interviewed at Army Children Internally Displaced Persons Camp. (L. o. Rann, Interviewer) Maiduguri, Borno State.

Ahmad, A. (2009). Jinn Magic or Mental illness (in the Light of Holy Qur'an and Hadith Anjum Quadri. Jaisinghpura University Gate Aurangabal .

Alkali. (2012). Nigeria Research Network NRN'Queen Elizabeth House. Oxford University.

Ash'ath. (n.d.). Sunan Abi- Dawud' Daru Al-kitab Al-arabi. Beirut, Lebanon.

Ba'alabaki, R. (1995). Al-Maurid Al-Arabi: A Modern Arabic-English Dictionary', . Beirut Lebanon: Dar El-Ilm Lilmalayin: 7th Edition.

Balogun. (2011). Syncretic Beliefs and Practices amongst Muslims in Lagos State with Special Reference to Yoruba Speaking People of Epe'A thesis Submitted to the University of Birmingham school of Philosophy for PhD.

Borno state Government. (1993). Borno state Handbook' Dadin-kowa ventures Jos Nigeria.

Cohen. (1967). The Kanuri of Bornu' Winston Inc. New York.

Dahiru. (1986). Qur'anic Studies in Borno: Development in the Nineteenth and Twentieth Centuries . Maiduguri: Linform Services.

Dein, \& Illaiee. (2013). Jinn and Mental Health: Looking at Jinn Possession in Modern Psychiatric Practice' University College London. London: The Psychiatric Bulletin NHS Foundation Trust.

Dierk. (1990). Ethno geneses from within Chadic State some Thoughts on the History of Kanem Borno. Presented at International Conference of Historical Sciences. Madrid.

Isma'il. (1987). Al-jami Al-sahih' Darul Shu'aib Cairo.

Kaka. (2009). An Auto-Ethnographical Study of Integration of Kanuri Traditional Health Practices into the Borno State Health Care System. PhD theses Durham University.

Kala, A. B. (2016, June 20). interviewed at Custom Area. (Farmer, Interviewer) Maiduguri Town, Borno State.

Khalid. (2010). The Preservation of Arabic 'Spiritual Medicine' in Hausa Society' Arabic/Ajami manuscripts. Resource for the Development of New Knowledge in 
Nigeria,Arewa House. Nigeria: Centre for Historical Documentation and Research A.B.U Zaria Kaduna.

Lawan Mai Sigalma, (. Y. (2016, July 26). interviewed at Internally Displaced Persons Camp, . Camp Ngala Road. (C. Priest, Interviewer) Maiduguri, Borno State.

Ma'rouf. (2003). Tahzeebu Dalilu Al-faliheen, Sharh Riyadh Al-salihin The Meadows of the righteous' Dar-Al- manara El-Mansoura Egypt. Egypt.

Makinta, Z. (2016, August 2). interviewed in Internally Displaced Persons Camp. (Tailor, Interviewer) Bama Road. Maiduguri.

Mayomi., \& M. J. (2014). A Decade Assessments of Maiduguri Urban Expansion (20022012). Global Journals Inc. (USA), 14.

Muhammad. (2004). Al-Ruqyah Al-Shar'iyyah' 2009 2nd Ed Daru Al-kutub Al-Ilmiyyah. Beirut.

Philip A. B. (1989). The Fundamentals of Tauheed'Al-hidaya U.K. U.K.

Rann, B. (2016, July 26). interviewed at Army Children Internally Displaced Persons Camp. (C. Priest, Interviewer) Borno State, Maiduguri.

Sediq. (2010). 'The Delusion by the Satan' Ibn Al-Jauzi. Egypt: Dar Almanar.

Sifawa. (1991). The Role of Kanem Borno Ulama in the Intellectual Development of the Bilad Al-Sudan' A paper presented at a conference organized. the centre for Transaharan studies University of Maiduguri.

Tijjani. (2005). Tradition and Modernity the Gamergu (Malgwa) of Northern-Eastern Nigeria. In P. T. London. London.

Tijjani. (2008). Malamih Anil Ulama'I fi Borno Abari Usuriha Al-Tarikhiyyah' AlArabiyyah. Journal of Arabic Culture National Arabic Language Village.

Usman H.M, John , \& Usman H. (2011). Contributions of Seasonal Migrants’ Fishermen towards fishing activities in Baga, Kukawa Local Government of Borno State. Journal of Environmental issues and Agriculture in Developing Countries, 2.

www.cometonigeria.com, . (n.d.). 